\title{
Water regime of metal- contaminated soil under juvenile forest vegetation
}

\section{Journal Article}

Author(s):

Menon, Manoj; Hermle, Sandra; Abbaspour, Karim C.; Günthardt-Goerg, Madeleine S.; Oswald, Sascha E.; Schulin, R.

Publication date:

2005-04

Permanent link:

https://doi.org/10.3929/ethz-b-000032245

Rights / license:

In Copyright - Non-Commercial Use Permitted

Originally published in:

Plant and Soil 271(1-2), https://doi.org/10.1007/s11104-004-2390-x 


\title{
Water regime of metal-contaminated soil under juvenile forest vegetation
}

\author{
Manoj Menon ${ }^{1,4}$, Sandra Hermle ${ }^{2}$, Karim C. Abbaspour ${ }^{3}$, Madeleine S. Günthardt- \\ Goerg $^{2}$, Sascha E. Oswald ${ }^{1}$ \& Rainer Schulin ${ }^{1}$ \\ ${ }^{1}$ Institute of Terrestrial Ecology, Swiss Federal Institute of Technology Zürich (ETHZ), Switzerland. ${ }^{2}$ Swiss \\ Federal Institute of Forest, Snow and Landscape (WSL), Birmensdorf, Switzerland. ${ }^{3}$ Swiss Federal Institute \\ of Environmental Science and Technology (EAWAG), Dübendorf, Switzerland. ${ }^{4}$ Corresponding author*
}

Received 4 May 2004. Accepted in revised form 23 August 2004

Key words: evapotranspiration, forest ecosystem, heavy metals, lysimeters, soil pollution, soil water regime

\begin{abstract}
In a three-year factorial lysimeter study in Open Top Chambers (OTCs), we investigated the effect of topsoil pollution by the heavy metals $\mathrm{Zn}, \mathrm{Cu}$, and $\mathrm{Cd}$ on the water regime of newly established forest ecosystems. Furthermore, we studied the influence of two types of uncontaminated subsoils (acidic vs. calcareous) and two types of irrigation water acidity (ambient rainfall chemistry vs. acidified chemistry) on the response of the vegetation. Each of the eight treatment combinations was replicated four times. The contamination (2700 mg kg${ }^{-1} \mathrm{Zn}, 385 \mathrm{mg} \mathrm{kg}^{-1} \mathrm{Cu}$ and $10 \mathrm{mg} \mathrm{kg}^{-1} \mathrm{Cd}$ ) was applied by mixing filter dust from a non-ferrous metal smelter into the upper $15 \mathrm{~cm}$ of the soil profile, consisting of silty loam (pH 6.5). The same vegetation was established in all 32 lysimeters. The model forest ecosystem consisted of seedlings of Norway spruce (Picea abies), willow (Salix viminalis), poplar (Populus tremula) and birch (Betula pendula) trees and a variety of herbaceous understorey plants. Systematic and significant effects showed up in the second and third growing season after canopies had closed. Evapotranspiration was reduced in metal contaminated treatments, independent of the subsoil type and acidity of the irrigation water. This effect corresponded to an even stronger reduction in root growth in the metal treatments. In the first two growing seasons, evapotranspiration was higher on the calcareous than on the acidic subsoil. In the third year the difference disappeared. Acidification of the irrigation water had no significant effect on water consumption, although a tendency to enhance evapotranspiration became increasingly manifest in the second and third year. Soil water potentials indicated that the increasing water consumption over the years was fed primarily by intensified extraction of water from the topsoil in the lysimeters with acidic subsoil, whereas also lower depths became strongly exploited in the lysimeters with calcareous subsoil. These patterns agreed well with the vertical profiles of fine root density related with the two types of subsoil. Leaf transpiration measurements and biomass samples showed that different plant species in part responded quite differently and occasionally even in opposite ways to the metal treatments and subsoil conditions. They suggest that the yearto-year changes in treatment effects on water consumption and extraction patterns were related to differences in growth dynamics, as well as to shifts in competitiveness of the various species. Results showed that the uncontaminated subsoil offered a possibility to compensate the reduction in root water extraction in the topsoil under drought, as well as metal stress.
\end{abstract}

\section{Introduction}

* FAX No: +41-1-6331123.

E-mail:manoj.menon@env.ethz.ch
Pollution of forest soils with heavy metals is not perceived to be a major problem because the risk 
of metals entering human food chain is much less than in polluted agricultural soils. Forest soils may be contaminated by heavy metals in particular due to atmospheric deposition from industrial or traffic (Kahle, 1993), inputs from shooting ranges (Darling and Thomas, 2003), uncontrolled waste disposal or afforestation of contaminated land. Where such pollution occurs, the resulting environmental risks may be even higher than on agricultural lands because of the lower $\mathrm{pH}$ values. Whereas agricultural soils are usually maintained close to neutral $\mathrm{pH}$ by application of lime and base-rich fertilizers, forest soils are often acidic and poorly buffered. As a result, metal mobility and phytoavailability may be much higher in forest soils than in cultivated soils at comparable total metal contents. This may not only lead to an increased risk of metal leaching into ground and surface waters, but also to higher ecotoxicity and impairment of ecosystem functions, which forests, for example, play in the hydrological and carbon cycle. Since metals cannot be decomposed, even a lowered input of metals still leads to further accumulation in both the upper soil layers and in tree roots (Wittig and Neite, 1989).

At landscape scale soil pollution by heavy metals has been found to reduce forest productivity (Pukacki and Kaminska-Rozek, 2002), vitality, biodiversity and stand structure (Chernenkova and Kuperman, 1999). Decreased biomass production is generally associated with reduced transpiration. Any decrease in transpiration results in a corresponding increase in soil water availability and higher regional discharge, which in turn promotes leaching of the metals into the subsurface.

At the plant scale, exposure to metal concentrations above a critical level has often been reported to negatively impact plant water relations and cause water stress (Barceló and Poschenrieder, 1990; Poschenrieder and Barceló, 1999), resulting in decreased transpiration due to stomatal closure (Kastori et al., 1992; Prasad, 1995; Schlegel et al., 1987). The responses to metal stress can be variable at times and even opposite. Metals induced enhanced transpiration occurs not only at higher metal concentrations (Angelov et al., 1993; Paul and de Foresta, 1981) but also at slightly toxic metal concentrations (Dueck, 1986; Kirkham, 1978). In former case, enhanced transpiration has been attributed to increased stomatal density because of reduction of leaf area (Paul and de Foresta, 1981) and in latter case, enhancement of transpiration is due to decreased osmotic potential and turgor maintenance in leaves (Costa and Spitz, 1997).

Due to their direct exposure, roots usually are the plant organs most severely affected by soilpolluting metals. Metal contamination of soils has been found to reduce root growth (Arduini et al., 1994, 1995; Ewais, 1997; Helmisaari et al., 1999), to inhibit root respiration (Karolewski and Giertych, 1994), and to interfere with nutrient uptake (Oberlander and Roth, 1978). Reduced root growth and functioning compromises the capability of a plant to extract soil water and nutrients. But reduction of transpiration under metal stress must not necessarily be associated with detectable root damage, it may be induced already at metal stresses that are below levels required to cause such effects (Barceló and Poschenrieder, 1990).

Irrespective of the mechanisms leading to toxic effects in the affected organism, the toxicity of metals in soil depends on how available the metals are to the target organism. Soil $\mathrm{pH}$ is a key factor for this availability (Kahle, 1993; Krebs et al., 1998). The solubility of metals like zinc and cadmium is particularly sensitive to $\mathrm{pH}$ variations in a weakly acidic to near-neutral range, which is the $\mathrm{pH}$ range of most soils in temperate humid climates (Fotovat and Naidu, 1998). Levels of $\mathrm{pH} 3$ or 3.5 in the upper soil horizons are quite common in forest stands of Central Europe and North America and under these conditions heavy metals are mobilized, pass into soil solution and are taken up by tree roots (Kahle, 1993). Because of the continuous acid deposition on forest soils, metal-polluted soils that do not have a serious toxicity problem at present due to a sufficiently high $\mathrm{pH}$, may suffer metal toxicity at a future time.

Effects of heavy metals on plant-water relations have mostly been studied in pot experiments with artificial soil substrates under climate chamber or greenhouse conditions or in hydroponic systems. Such studies are useful to understand specific mechanisms and processes, but they cannot represent conditions of real ecosystems, where plants grow under competition for above-ground, as well as below-ground resources. Moreover, particularly in hydroponic cultures but also in most pot experiments plants are exposed to 
homogeneous metal stress in the root zone. In reality, where soils are contaminated with metals from atmospheric deposition or agricultural applications of metal-containing substances, the contamination is usually concentrated in the topsoil, while the subsoil often remains relatively unaffected, because of the slow movement of metals. Root growth has been found to avoid zones of metal stress in soils, where this is possible due to uneven distribution of the pollution (Palazzo et al., 2003, Romney et al., 1981; Schwartz et al., 1999). Thus, the responses of plants on elevated soil metal concentrations may be quite different depending on the spatial distribution of toxic metals in soil in relation to the distribution of required resources, such as water and nutrients. The high spatial heterogeneity of soils, however, makes it in general very difficult to isolate the effects of individual factors, such as metal pollution in field experiments.

The objective was to study the effect of topsoil heavy metal pollution, the influence of uncontaminated subsoil types (acidic and calcareous) and rainfall acidity on plant growth and water regime operating under carefully defined controlled conditions (simulated juvenile forest ecosystem), including the effect of imposed drought conditions on water extraction. In order to identify the effects of these factors, a factorial lysimeter study with four replications of each treatment combination was designed. The experiments simulate re-forestation of an agricultural soil, which has been polluted by deposition of metal-containing dust from a nearby non-ferrous metal smelter.

\section{Materials and methods}

\section{Open top chambers and lysimeter compartments}

The experiments were performed in the Open Top Chamber (OTC) facility of the Swiss Federal Institute of Forest, Snow and Landscape Research (WSL) at Birmensdorf, Switzerland. The institute is situated close to the city of Zurich at an altitude of $450 \mathrm{~m}$ above sea level. The facility consists of 16 hexagonal chambers, which are $3 \mathrm{~m}$ high above ground and $3 \mathrm{~m}$ wide (internal distance between opposing hexagonal sides). The chambers are equipped with glass walls and roofs. The side glass walls are not completely closed to allow ventilation. The roofs are closed automatically at the onset of rain. Below ground surface, each chamber is divided into two $1.5 \mathrm{~m}$ deep concrete-walled soil compartments, each with a surface area of $3 \mathrm{~m}^{2}$, which are used as non-weighable lysimeters. A cylindrical tube of $1.25 \mathrm{~m}$ diameter between the two soil lysimeters allows access to the three bottom outlets collecting the discharge for each compartment (Figure 1).

\section{Soils and application of heavy metals}

The lower $0.5 \mathrm{~m}$ of each compartment was filled with a three-layer drainage packing consisting of a fine quartz layer at the bottom, a coarse quartz sand layer at the top and a layer of intermediate texture in between. Before placing the drainage packing into the lysimeters, the sand was thoroughly washed with water to remove fine sediments. On top of the drainage packing, a $0.8 \mathrm{~m}$ subsoil layer was packed in the autumn of 1999. In one compartment of each chamber was used calcareous sandy loam originating from a Calcaric Fluvisol (along the river Aare), while in the other compartment was used acidic loamy sand originating from a Haplic Alisol (along the river Rhein). Both sampling sites were under mixed deciduous forests situated in the vicinity of Zurich, Switzerland. For the topsoil in all

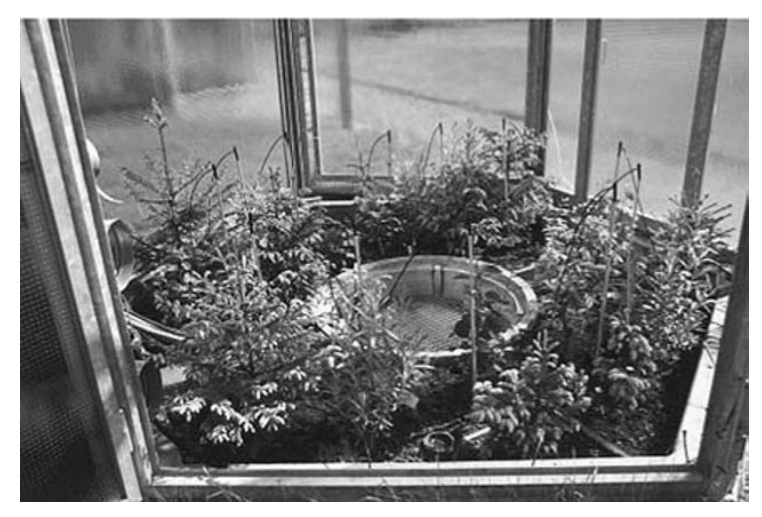

Figure 1. View into the Open Top Chambers (OTC) in spring 2002. Each half chamber contained 14 juvenile trees $[6$ spruce (P. abies), 4 poplar (P. tremula), 2 birch (B. pendula) and 2 willow (S. viminalis)] and various understorey plants. In the centre, the access tube to the bottom outlets of the soil compartments is visible. 
Table 1. Physical and chemical properties of the soil types used in the experiment

\begin{tabular}{llll}
\hline & Topsoil & Acidic subsoil & Calcareous subsoil \\
\hline Texture $(\%$ sand; silt; clay) & $36 ; 49 ; 15$ & $87 ; 8 ; 5$ & $74 ; 16 ; 10$ \\
$\mathrm{pH}(0.01 \mathrm{M} \mathrm{CaCl})$ & $6.55 \pm 0.12$ & 4.2 & 7.4 \\
$\mathrm{C}_{\text {inorg }}(\mathrm{g} / \mathrm{kg})$ & $<1$ & $<1$ & 21 \\
$\mathrm{C}_{\text {org }}(\mathrm{g} / \mathrm{kg})$ & 15.1 & 3.2 & 11.2 \\
$\mathrm{~N}_{\text {tot }}(\mathrm{g} / \mathrm{kg})$ & 1.5 & $<0.3$ & 0.6 \\
$\mathrm{C}_{\text {org }} / \mathrm{Ntot}$ & 10 & $\mathrm{n} . \mathrm{d}$. & 18 \\
$\mathrm{P}_{\text {extractable }}(\mathrm{mg} / \mathrm{kg})$ & 1160 & 298 & 296 \\
$\mathrm{P}_{\text {org }}(\mathrm{mg} / \mathrm{kg})$ & 862 & 84 & 54 \\
$\mathrm{P}_{\text {avail }}(\mathrm{mg} / \mathrm{kg})$ & $49 \pm 5$ & 18 & 11 \\
$\mathrm{~K}_{\text {exch }}(\mathrm{mg} / \mathrm{kg})$ & 283 & 23 & 21 \\
$\mathrm{CEC}(\mathrm{mmolc} / \mathrm{kg})$ & 55 & 12 & 67 \\
Base saturation $(\%)$ & 99.9 & 35.9 & 99.9 \\
\hline
\end{tabular}

lysimeters was used a slightly acidic loam that was obtained from an arable field (from Birr), which had been excavated for road construction. The properties of the three soil materials are given in Table 1.

A $0.15 \mathrm{~m}$ layer of the topsoil was placed on the top of the subsoil. In half of the chambers, the topsoil was then artificially contaminated with filter dust from a non-ferrous metal smelter. The chemical composition of the dust is given in Table 2. The dust was mixed into the topsoil by hand, after tensiometers and other instrumentation had been installed in the subsoil. The average concentration of $\mathrm{HNO}_{3}$-extractable metals in the contaminated topsoils after mixing were $2700 \mathrm{mg} \mathrm{kg}^{-1} \mathrm{Zn}, 385 \mathrm{mg} \mathrm{kg}^{-1} \mathrm{Cu}, 63 \mathrm{mg} \mathrm{kg}{ }^{-1}$ $\mathrm{Pb}$ and $10 \mathrm{mg} \mathrm{kg}^{-1} \mathrm{Cd}$.

\section{Vegetation}

The same selection of trees and herbs was planted in each soil compartment. The selected species were birch (Betula pendula L.), willow
(Salix viminalis L.), and poplar (Populus tremula L.). The herbaceous plant species, which were chosen to represent different growth strategies, were wood sedge (Carex sylvatica Hudson), ramsons (Allium ursinum L.) and tansy (Tanacetum vulgare L.). All plants were planted in spring of the year 2000. The trees were arranged in such a way that different species were mixed in distribution and that the ground was covered as evenly as possible (Figure 1). Deciduous and coniferous trees were planted at fixed positions (without regarding provenance in the case of spruce), but the various understorey plant species were distributed at random in between the trees. Measurements started with the second growing season, i.e. in spring of 2001.

\section{Irrigation}

Irrigation was applied by means of sprinklers (6 per soil compartment) with computer-controlled flow meters. The height of the sprinklers was chosen so that splashing of water was avoided.

Table 2. Metal contents of the applied heavy metal dust

\begin{tabular}{lcllll}
\hline Element & $\mathrm{HNO}_{3}$ extractable $(\mathrm{g} / \mathrm{kg})$ & \multicolumn{4}{c}{ Chemical form $(\mathrm{g} / \mathrm{kg})$} \\
\cline { 3 - 5 } & & Elemental & Oxide & Carbonate & Phosphate \\
\hline $\mathrm{Zn}$ & 755.0 & - & 940.0 & - & - \\
$\mathrm{Cu}$ & 85.5 & 48.6 & - & 71.7 & - \\
$\mathrm{Pb}$ & 15.2 & - & 16.4 & - & - \\
$\mathrm{Al}$ & 6.1 & - & - & - & 7.4 \\
$\mathrm{Ca}$ & 3.0 & - & 2.4 & - & - \\
$\mathrm{Na}$ & 1.8 & - & & & - \\
\hline
\end{tabular}


The irrigation was scheduled based on the tensiometer measurements, so as to keep the soil moisture content around field capacity. Irrigation was given during nights with a break of one day prior to soil water potential and water content measurements. In eight OTCs, irrigation water had the chemical composition of ambient rain (pH 5.5). For the irrigation of the other eight OTCs, $\mathrm{HCl}$ was added until the $\mathrm{pH}$ reached a value of 3.5. Irrigation was discontinued during the non-growing seasons. In 2002, a 3-week drought period was imposed purposely from May to June by reducing irrigation. In 2003 irrigation was scheduled to correspond to the longterm rates of monthly average rainfalls, although the summer was exceptionally dry and hot from June to September.

\section{Measurements}

\section{Soil water potential}

In each lysimeter, eight tensiometers were installed vertically, two each at 10-15, 35-40, 60-65 and 85-90 cm depths (position of ceramic cups), but the midpoint of each tensiometer cup from above depths is taken (i.e., 12, 36, 62 and $88 \mathrm{~cm})$ to represent each depth. Soil water potentials were recorded manually normally once a week during the growing season, using the method of Marthaler et al. (1983). During the imposed drought period, measurements were taken every 2-3 days.

\section{Drainage and water content}

The drainage water was collected in plastic containers at the bottom outlets of each lysimeter. The volume of the drainage water was determined by volumetric cylinders, into which the containers were emptied weekly by means of a vacuum pump.

Soil water content was measured by Time Domain Reflectometry (TDR), using a Tektronix 1502B instrument. TDR probes of $25 \mathrm{~cm}$ length were installed vertically at $0-25,25-50,50-75$ and $75-100 \mathrm{~cm}$ depth. The recorded TDR signals were calibrated and analysed using the procedure of Roth et al. (1989). Evapotranspiration was determined from the following water balance expression:

$$
E T=I-D-\Delta S,
$$

where $E T$ is evapotranspiration, $I$ is irrigation, $D$ is drainage, and $\Delta S$ is the change in soil water storage.

\section{Biomass}

Above-ground biomass was harvested at the end of the growing season 2001 except for the very small birch trees and little tree seedlings in the understorey. The harvest included total aboveground biomass of the herbaceous plant species Tanacetum vulgare and Carex sylvatica. Poplars and willows were cut at $10 \mathrm{~cm}$ above ground. In the case of spruce, only one branch was taken per tree from the second whirl from the top and separated into sections grown in 2000 and 2001. The whole tree biomass of spruce was estimated from these samples using allometric relationships between twig aliquots and whole tree biomass, which had been determined in a previous experiment by regression analyses (Egli et al., 1998). Dry weights were determined after oven-drying at $65^{\circ} \mathrm{C}$ till constant weight was attained.

At the end of the growing season 2003, six soil cores of $5 \mathrm{~cm}$ diameter and $75 \mathrm{~cm}$ depth were sampled from each compartment at the same relative positions using a hollow cylindrical coring device of type HUMAX (brand name). The cores were divided into sections representing $0-12.5, \quad 12.5-25,25-50$ and $50-75 \mathrm{~cm}$ depth. Roots were separated manually by wet-sieving, washed and oven-dried at $65^{\circ} \mathrm{C}$. Root density was determined as total dry biomass of fine roots ( $<2 \mathrm{~mm}$ diameter) per unit volume of soil.

\section{Transpiration}

A portable gas-exchange measuring unit (open system; LiCor-6400) was used to measure transpiration rates of single willow and poplar leaves. The measurements were performed in 12 OTCs (3 replicates each per treatment and soil type, 2 trees per species and chamber, 4 fully grown leaves per tree) at the end of June 2001, between 10 a.m. and 4 p.m. at a quantum flux of 100 $1000 \mu \mathrm{mol} \mathrm{m}^{-2} \mathrm{~s}^{-1}$. Four leaves of each tree were 
selected representing different positions in the tree with respect to sunlight exposure. Measurements were extrapolated to total tree transpiration by multiplication of mean transpiration with leaf area per tree. To obtain the latter, the area of 10 leaves of each deciduous tree of the experiment was measured in autumn 2001 using a MK2 leaf area meter (Delta-T Devices LTD, Cambridge, England). The total leaf area per tree was then estimated by multiplying the area/ weight factor with the total dry foliage weight of the plant.

\section{Statistical design and analysis}

Each of the four combinations of topsoil contamination (with/without heavy metal dust) and irrigation water acidity (ambient/acidified) was replicated in four chambers using a Latin Square design (Figure 2). Combined with the two types of subsoil in each OTC (acidic and calcareous), this gave a fully balanced factorial design of $2 \times 2 \times 2$ treatments with four replications (see Figure 2).

Treatment effects were analysed by GLM (General Linear Model) using SYSTAT (version
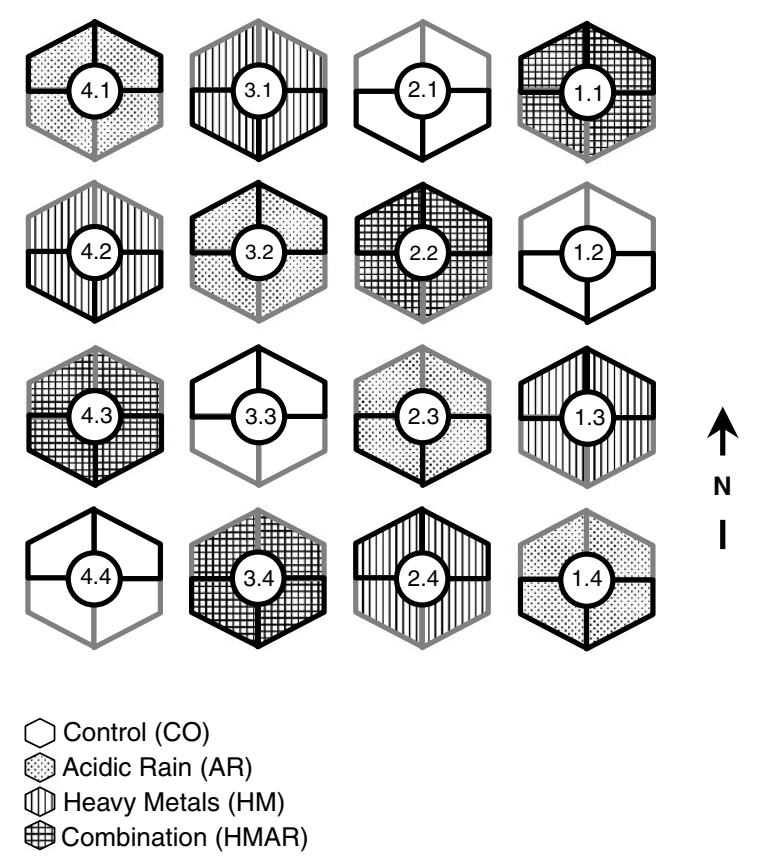

Figure 2. Arrangement of open top chambers (OTCs). Each OTC contains two non-weighing lysimeters (compartments) one with calcareous subsoil (black border), the other with acidic subsoil (grey border).
10.0) and SAS (version 8.2). The following abbreviations are used to denote treatments: HM, heavy metal contaminated topsoil (and ambient rain); AR, acidified 'rain' (and no contamination); HMAR, combination of heavy metal contaminated topsoil and acidified rain; $\mathrm{CO}$, control (no contamination, ambient rain). The error bars were calculated by dividing standard deviation by the square root of the number of observations.

\section{Results}

\section{Soil water potential}

In the first year, the average soil water potentials in each treatment during most of the time varied between -20 and $-80 \mathrm{hPa}$ in the topsoils and only occasionally dropped below this range (Figure 3 ). In the following 2 years soil water potentials below this range were much more frequent due to the artificially imposed drought period in 2002 and the exceptionally dry summer in 2003. Because the variability between tensiometers increased almost in proportion to the average soil water potential, we chose to display the logarithms of their (negative) values in the figures. A high log value, thus, corresponds to a low soil water potential, which is equivalent to a high capillary water tension or suction or, in other words, to a dry soil. The lowest soil water potentials were observed at the end of the reduced irrigation period in June 2002 (Figure 3). During this period some tensiometers stopped working, as the soil water potentials exceeded the lower limit of their measurement range of around $-800 \mathrm{hPa}$.

Heavy metal contaminated topsoils maintained significantly higher soil water potentials than controls, indicating that less water was extracted from contaminated than from uncontaminated topsoil (Table 3). This effect was particularly pronounced in the dry summer of 2003, i.e. in the third growing season. The acidity of the irrigation water had no significant effect on the recorded soil water potentials. Neither did the type of subsoil significantly influence topsoil soil water potentials, although in metal treated soils topsoil soil water potentials tended to be 

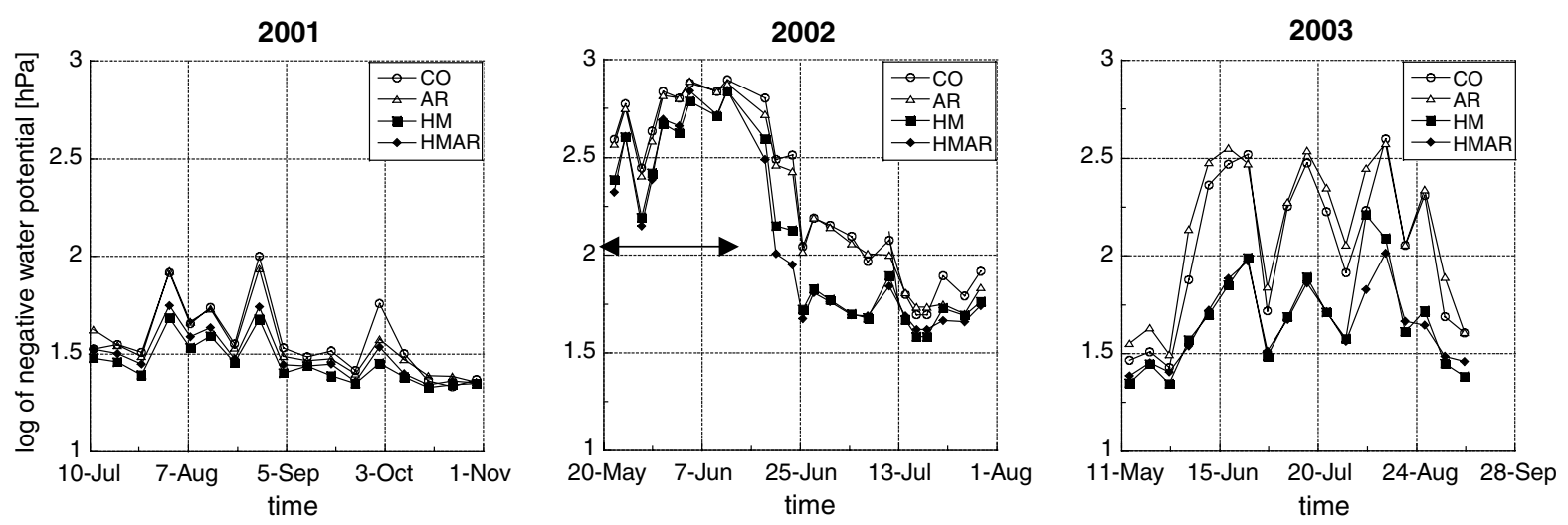

Figure 3. Year-to-year effects of heavy metal and irrigation water acidity on topsoil (12 cm depth) water potential (average logarithms of negative potential values). The symbol $\leftrightarrow$ denotes the induced drought period.

lower in acidic than in calcareous subsoil in 2003.

In the first two seasons, the type of subsoil, however, had a strong influence on soil water potentials in the subsoil. As illustrated in Figure 4 , this influence became increasingly pronounced at lower depths and during the imposed drought period and gradually decreased again, when the soil was re-wetted in the weeks thereafter. Soil water potentials decreased faster in the calcareous than in the acidic subsoil. At the lowest two depths of measurement they also reached lower peak values in the calcareous subsoil. In the following season the overall

Table 3. ANOVA results of the different treatments including their significance at $5 \%$ level compared to the controls

\begin{tabular}{llllll}
\hline Measurements & Year & \multicolumn{3}{c}{ Factors } \\
\cline { 4 - 6 } & & HM* & AR & HM*AR & Subsoil \\
\hline Evapotranspiration $(n=24)$ & 2001 & 0.032 & n.s. & 0.003 & 0.000 \\
Evapotranspiration $(n=24)$ & 2002 & 0.001 & n.s. & n.s. & 0.002 \\
Evapotranspiration $(n=24)$ & 2003 & 0.001 & n.s. & n.s. & n.s. \\
Topsoil soil water potential $(n=64)$ & 2001 & 0.000 & n.s. & n.s. & n.s. \\
Topsoil soil water potential $(n=64)$ & 2002 & 0.000 & n.s. & n.s. & n.s \\
Topsoil soil water potential $(n=64)$ & 2003 & 0.000 & n.s. & n.s. & n.s \\
Subsoil soil water potential $(n=32)$ & 2001 & n.s. & n.s. & n.s. & 0.000 \\
Subsoil soil water potential $(n=32)$ & 2002 & n.s. & n.s. & n.s. & 0.000 \\
Subsoil soil water potential $(n=32)$ & 2003 & n.s. & n.s. & n.s. & n.s \\
Transpiration per whole tree & & & & & \\
S. viminalis & 2001 & n.s. & n.s. & n.s. & 0.0028 \\
$P$. tremula & 2001 & 0.0244 & 0.0458 & n.s. & 0.0527 \\
Above ground biomass per half chamber & & & & & \\
Understorey plants & 2001 & n.s. & 0.0418 & n.s. & 0.0001 \\
Deciduous trees & 2001 & 0.028 & n.s. & n.s. & 0.0001 \\
$P$. abies & 2001 & n.s. & n.s. & n.s. & n.s. \\
Above ground biomass per half chamber (in total) & & & & & n.s. \\
& 2000 & n.s. & n.s. & n.s. \\
& 2001 & n.s. & n.s. & n.s. & 0.0001 \\
& 2002 & n.s. & n.s. & n.s. & n.s. \\
\hline
\end{tabular}

$* \mathrm{HM}=$ heavy metal contaminated soil, $\mathrm{AR}=$ acidic rain, n.s. $=$ not significant. 

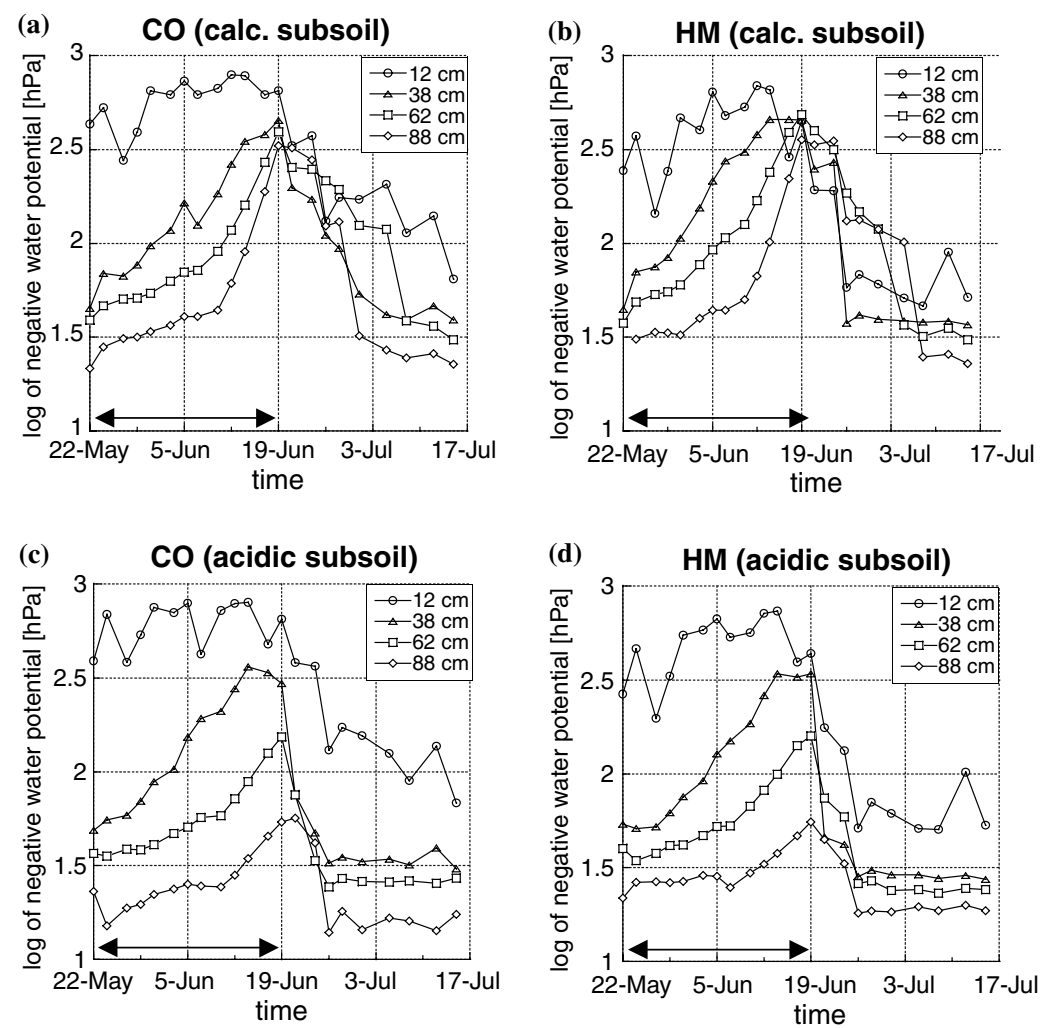

Figure 4. Effect of subsoil type and heavy metals on soil water potential development during the induced period of drought (from 22 May to 19 June) in 2002 at various depths $(12 \mathrm{~cm}$ represents topsoil). The sub-figures compare control and heavy metal treatments, and between subsoil types. The symbol $\leftrightarrow$ denotes the induced drought period.

differences in soil water potentials between the two subsoils were no longer significant.

Overall, the metal treatment of the topsoil had no significant effect on the soil water potentials in the subsoil, although Figure 4 suggests that the decrease in soil water potential during the drought period in June 2002 may have been more persistent under uncontaminated than under contaminated topsoil.

A more subtle metal effect on soil water potentials emerges when we compare different depths in Figure 4. During periods of unrestricted water supply (at the start of the imposed drought period and after full re-wetting of the soil profiles) soil water potentials increased with depth in a similar way in all treatments. During the drought in 2002 the vertical soil water potential gradients gradually decreased, indicating a shift of root water extraction activity to lower depth in order to compensate for reduced water availability in the upper parts of the profile. Eventually, the verti- cal soil water potential gradients even reversed in some treatments, because of the earlier response of soil water potentials in the topsoil and the increasingly delayed responses on drying and re-wetting with increasing depth in the subsoils. This shift in water extraction towards lower depths was pronounced on calcareous than on acidic subsoil. At the end of the reduced irrigation period in June 2002 the average soil water potential in calcareous subsoils even reached lower values under metal-contaminated topsoil than in the controls. It appears that under metal stress in the topsoil roots tried to compensate even more for reduced irrigation water supply by enhanced activity in the subsoil (relative to the topsoil) than in the controls, especially in the calcareous subsoil (Figure 5a, b). In 2003, when dry and hot conditions lasted for several months, while irrigation was continued at pre-scheduled rates, soil water potentials remained higher in the subsoil than in the topsoil. However, as at the end of the artificial 


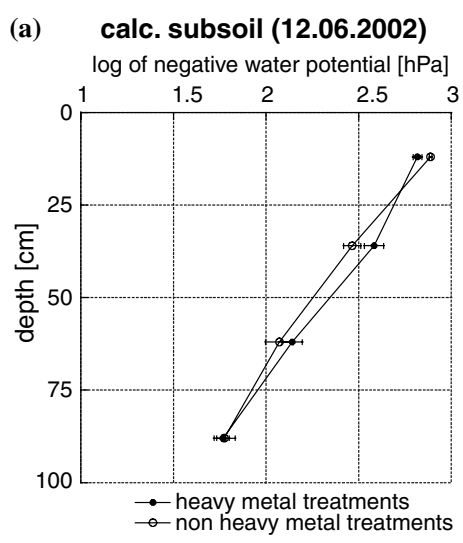

(c) calc. subsoil (25.06.2003)

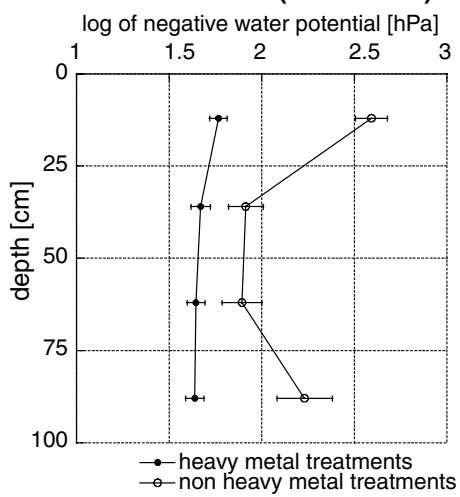

(b) acidic subsoil (12.06.2002)

log of negative water potential [hPa]

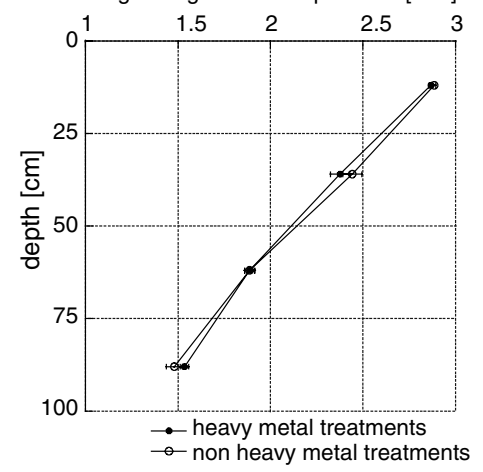

(d) acidic subsoil (25.06.2003)

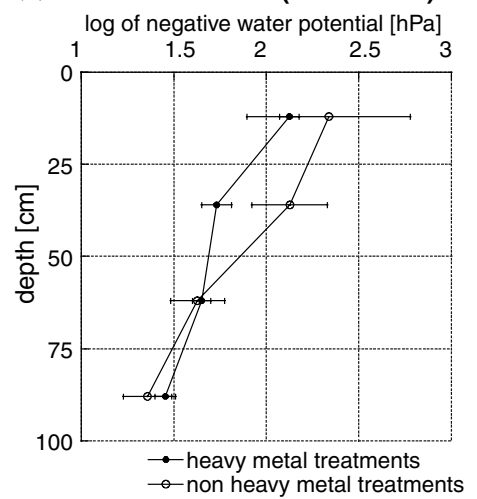

Figure 5. Effect of subsoil types and heavy metals on profile water potential during the peak drought days in 2002 and 2003.

drought and in the beginning of the subsequent recovery in 2002, decreases and even reversals of the vertical potential gradients were observed in the calcareous subsoil after peaks of water stress in the topsoil in 2003 (Figure 5c). No such reversals were observed in acidic subsoil (see e.g. profile in Figure 5d). Figure 5 not only shows that soil water potentials increased (i.e. logarithms of negative potentials decreased) much more with depth in the uncontaminated than in the contaminated topsoils, but also that the increase was stronger above acidic than calcareous topsoil for a given treatment.

\section{Water balances}

Figure 6 shows the treatment effects on the overall water balances of the lysimeters. Metal contamination had a weak, but significant effect (Table 3). The metal effect became more evident from year-to-year, as tree canopies closed and ground area was covered. In contrast, the subsoil had significant effects in the first two years, but not in the third (Table 3). In the growing season of 2001 ET was in average $14.7 \%$ and in $2002-11.3 \%$ higher in the lysimeters with calcareous subsoil than from lysimeters with acidic subsoil. Contrary to our expectation that addition of acidity would enhance the metal effect, acidic rain did not reduce evapotranspiration. Rather there was a tendency over the years that evapotranspiration was larger with acidic than with ambient rain chemistry, although the trend did not become statistically significant.

\section{Transpiration and biomass}

Transpiration rates per tree were not only significantly higher in P. tremula $\left(5.18 \mathrm{mmol} \mathrm{H}_{2} \mathrm{O} \mathrm{s}^{-1}\right)$ than in $S$. viminalis $\left(3.92 \mathrm{mmol} \mathrm{H}_{2} \mathrm{O} \mathrm{s}^{-1}\right)$ at the dates selected for measurements in absence of metal stress, but the two species also responded quite differently to the heavy metal pollution in 


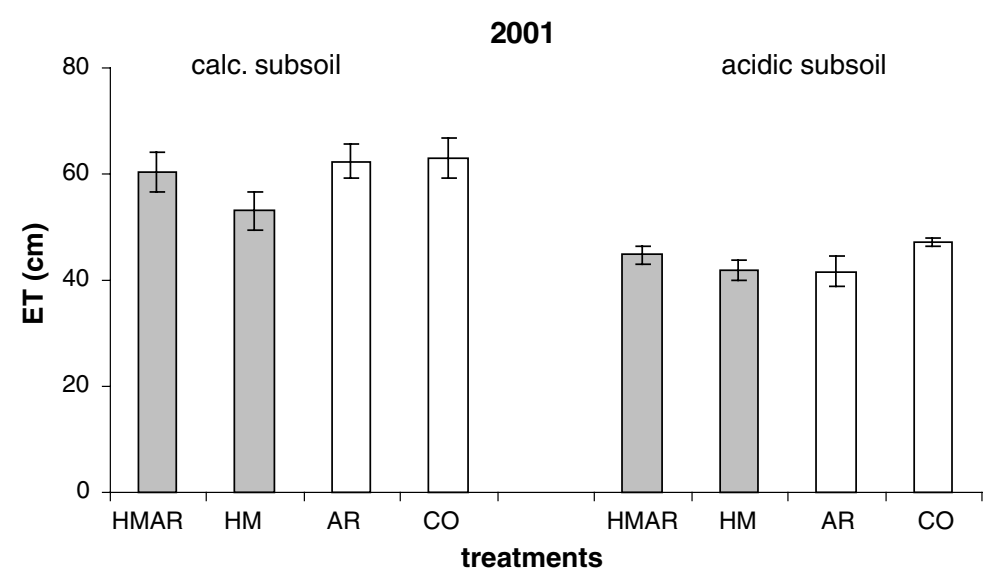

2002

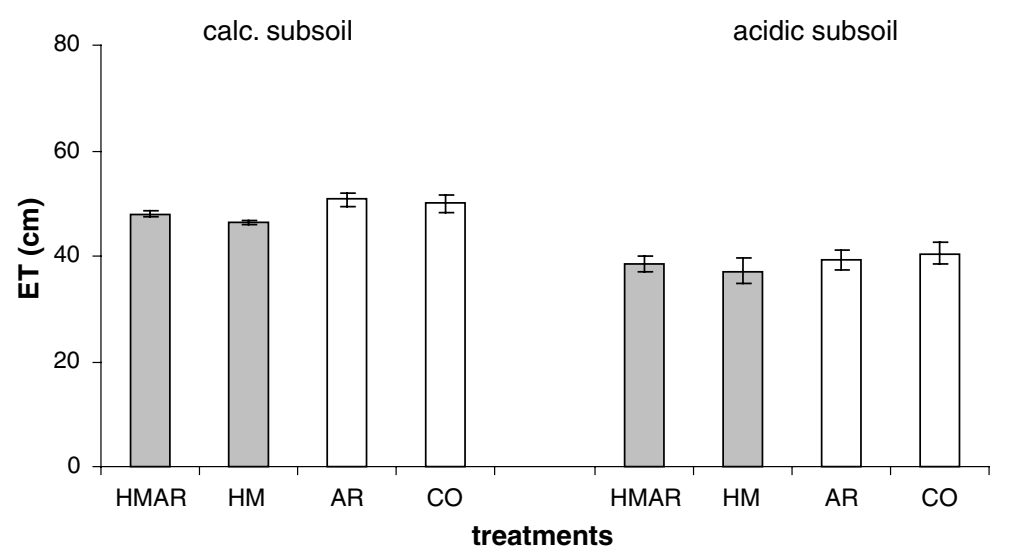

2003

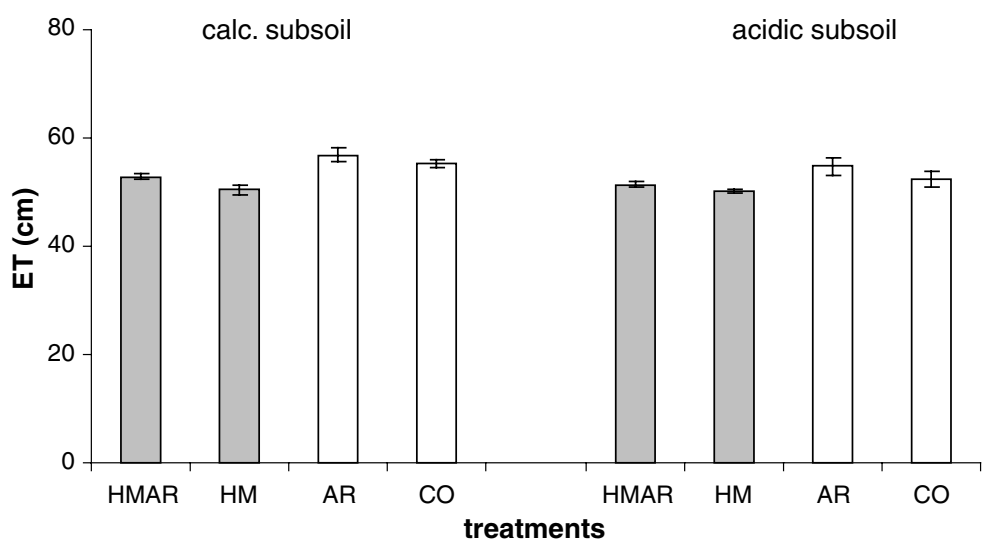

Figure 6. Total evapotranspiration in the three successive growing seasons from 2001 to 2003 . The total amount of irrigation during the growing season in year 2001, 2002 and 2003 was $75,57.6$ and $59.8 \mathrm{~cm}$, respectively.

the topsoil (Figure 7). Heavy metals significantly reduced the transpiration rates in $P$. tremula $(P=0.024)$, whereas they tended to enhance transpiration in $S$. viminalis.
The above-ground biomass in Figure 8 show strong fluctuations from year-to-year. In the growing season 2001, trees and herbs together produced much more above-ground biomass 


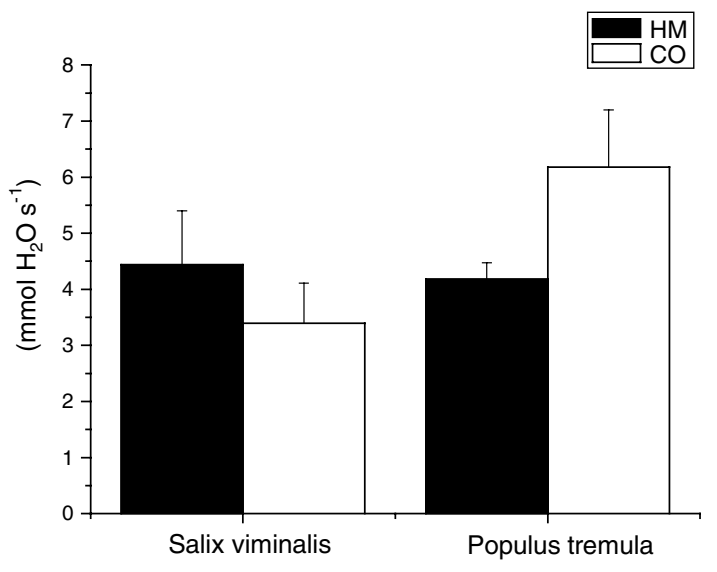

Figure 7. Transpiration rate per tree in 2001 for the heavy metal compared to the control treatment (mean $+\mathrm{SE}$; $\mathrm{n}=12$ ); comparison of willow and poplar.

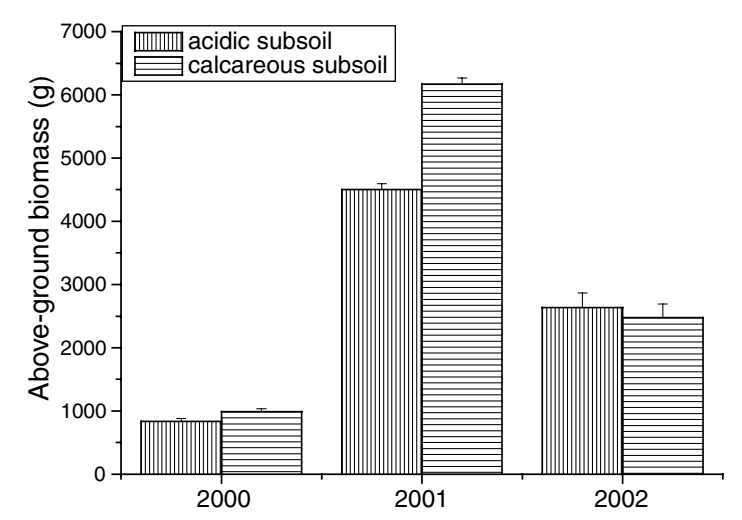

Figure 8. Annual total above-ground biomass production of trees and understorey plants on acidic and calcareous subsoil type (means + SE; 2000: $\mathrm{n}=18 ; 2001,2002: \mathrm{n}=16$ ).

than in 2002. Moreover, in 2001 total biomass production was much higher on calcareous than on acidic subsoil, whereas no above-ground growth difference was found between the two subsoils in the following year (Figure 8, Table 3). Growth responses in lysimeters where topsoils were contaminated with heavy metal strongly differed between plant species. On the calcareous subsoil, metals distinctly reduced the growth of the deciduous trees, while they enhanced the growth of the herbs and did not affect the biomass of spruce (Figure 9, Table 3). None of these groups showed a metal treatment effect on the biomass production of the acidic subsoils.

Total biomass production was approximately proportional to evapotranspiration, but, in light

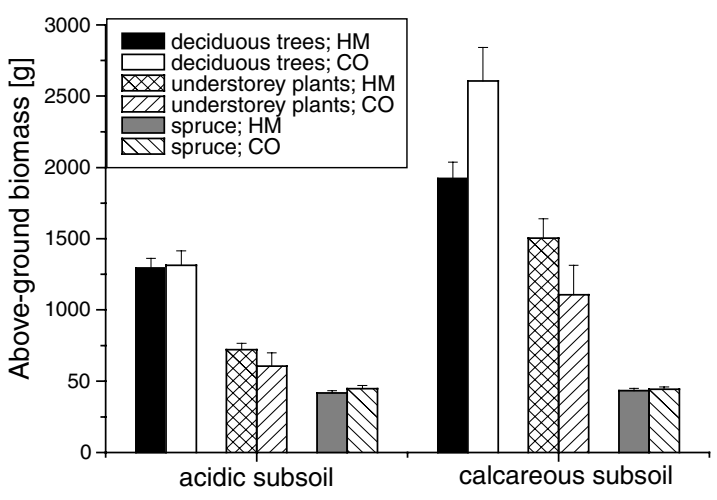

Figure 9. Influence of topsoil heavy metal contamination and subsoil type on above-ground biomass production in 2001, for different groups of species (mean $+\mathrm{SE} ; \mathrm{n}=8$ ).

of the uncertainty in the estimates involved, further analysis of whole-ecosystem water use efficiency (the ratio of aboveground biomass to evapotranspiration) did not reveal any significant insights.

The metal treatment had a strong effect on the fine root density (Figure 10). In the presence of metals fine root growth was reduced by roughly $50 \%$ in the topsoil above both types of subsoil. This metal effect decreased with depth and little or no differences between metal treatments and controls were found below $25 \mathrm{~cm}$ depth. Also the subsoil influenced the vertical profiles of fine root density distribution. Calcareous subsoil favoured deeper rooting, whereas acidic subsoil resulted in higher fine root densities in the topsoil.

\section{Discussion and conclusions}

The metal contamination in the topsoil produced weak, but nonetheless significant effects on the soil water relations of the investigated juvenile forest ecosystem. Evapotranspiration was reduced under metal stress. The effect became clearer from year-to-year with progressing development of the young stands. At the same time the subsoil effect on evapotranspiration decreased, while there appeared to be a slight tendency of higher ET in the lysimeters, receiving acidified irrigation. The latter two trends were not expected. On the contrary, addition of acidity to the metal-contaminated soils was expected to increase the availability of the metals and, thus, to amplify the 


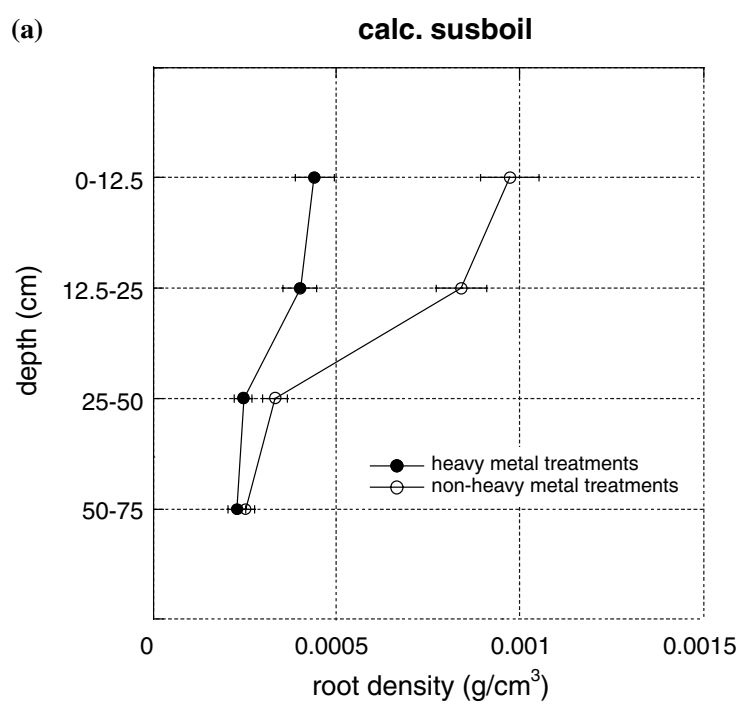

(b)

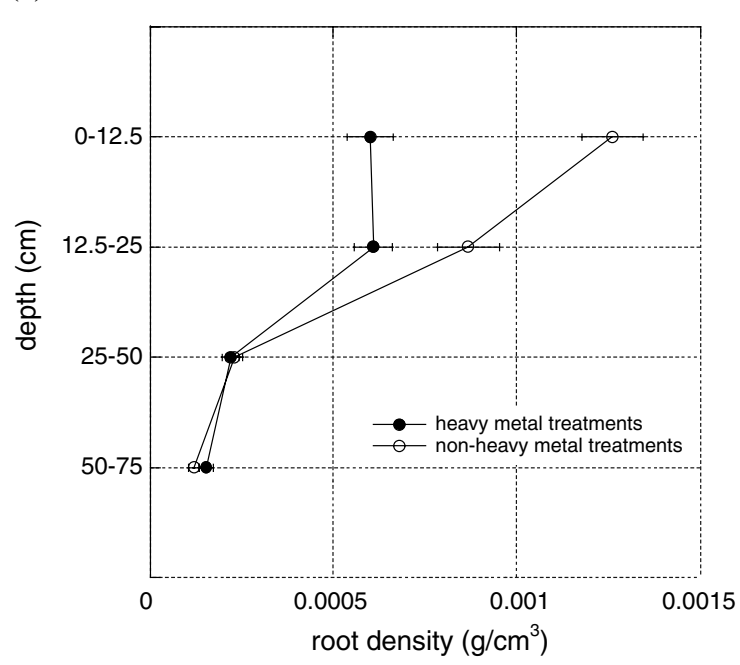

Figure 10. Vertical profiles of the fine root density distribution at the end of the third growing season in the lysimeters (a) with calcareous subsoil and (b) with acidic subsoil.

heavy metal-induced stress effects. The responses of different plant species or groups, as well as the soil water potentials at different depths, revealed the complexity of the system, while providing some hints on possible explanations. The measured soil water potentials can be interpreted in terms of the vigour, with which the roots extracted water from the respective soil depths. Under unrestricted water supply, root water extraction activity was by far the highest in the topsoil, as would be expected under such conditions (Figure 3, year 2001). Under water stress (induced drought conditions), the root activity gradually shifted into the subsoil, in particular in the calcareous subsoil, which provided more favourable growth conditions, especially for deciduous trees than the less fertile acidic subsoil (Table 1). According to measurements of metal concentrations in soil solution extracts, significant metal leaching into either of the two subsoils can be ruled out (Rais, 2004), thus the subsoil represents a zone for root activity not directly affected by the heavy metal stress. This explains why, relative to the root activity in the topsoil, the compensatory water extraction from the subsoil observed during periods of water shortage was more pronounced in the metal treatments than in the controls particularly evident in calcareous subsoil (Figure 4). The observed shifts in root water extraction activity must not necessarily reflect responses of individual plant species, but may equally well result from a shift in the relative contributions of plants with different root systems to water extraction. The water balances give total soil water losses due to evaporation and transpiration, but cannot differentiate between contributions of the various system components. The transpiration measurements on the other hand give no information on the water balance of the system, but provide insight into the variation of responses between different tree species. The leaf measurements at selected dates showed that willow trees transpired rather more water under metal stress, while the opposite was found for poplars. Willows are known for their high tolerance to soil metal pollution (Pulford and Watson, 2003). As we do not know how the two species in monoculture would have reacted to the treatments, we cannot say whether this observation only reflects the different tolerances to metal stress of the two species or whether competition effects played an additional role. Nonetheless, the latter seems likely if we consider also the understorey growth, which profited from reduced tree growth in the metal treatments, at least for calcareous subsoil (Figure 9).

Shifts in the relative root system development between the different plant species or groups of plant species also provide a likely and plausible explanation for the observed changes in the patterns of treatment effects on water balances and soil water potentials between successive seasons. In particular, this could explain why water 
consumption increased much more on the acidic than on the calcareous subsoil from 2002 to 2003, making the subsoil effect on evapotranspiration disappear in 2003. Judging from the soil water potential measurements, the increased evapotranspiration on acidic subsoil was primarily due to a stronger exploitation of water in the upper subsoil, while in the lysimeters with calcareous subsoil the lower part of the subsoil contributed most to the slight increase in water consumption. This suggests that from the second to the third year of the experiment, root systems developed more in topsoil with acidic subsoil, while in compartments with calcareous subsoil more root growth occurred in deeper soil layers.

The root density data are in good agreement with this interpretation. Root growth may have been reduced in the acidic subsoil, because of nutrient scarcity. It may also have been inhibited due to aluminium toxicity in the acidic subsoil (Table 1). Single-species root growth allocation and toxicity alone, do not explain why the difference in evapotranspiration between lysimeters with different subsoils disappeared in the third year. All these observations can be reconciled, however, if we consider that they are the combined effects resulting from the growth and activity of a mixed vegetation, in which different species with different growth dynamics and responsiveness to site conditions were competing with each other.

It appears that biomass production was affected by metal stress, where growth conditions were favourable (in calcareous subsoil), while in the acidic soils, the heavy metal effect was probably masked by the unfavourable growing conditions. The biomass data suggest that the deciduous trees suffered on the acidic subsoils and that in comparison with spruce trees developed much better. Spruce is known to develop rather shallow root systems and be more tolerant to acidic soil conditions, and to grow slower than willows and poplars. A shift to a stronger development of spruce relative to the deciduous trees with time on the acidic subsoils, would agree well with the differences in fine root distribution profiles found at the end of the experiment, as well as with the observed shifts in water extraction. It would also provide a plausible explanation for the observation that evapotranspiration tended to be larger under acidified than under ambient rainfall chemistry, including the fact that this tendency became obvious only in the last experimental year.

As acidic rain had no effect or even slight enhancing effect on water consumption, we conclude that the acidity of the irrigation water did not significantly increase soil metal toxicity in the system. As heavy metal treatment caused a significant reduction in evapotranspiration, any mobilisation of metals due to the addition of acidity into the topsoil, should have further reduced evapotranspiration. So, it seems likely that some additional effect other than increasing metal solubility and thereby toxicity was exerted by the acidic rain treatment, compensating for such mobilisation. It would be in agreement with the hypothesis of shifts in competitive strength between different species, if the increase in evapotranspiration was due to an increased growth of the spruce, favoured against the competition of the deciduous trees by more acidic soil conditions.

Metals have been reported to reduce transpiration in various ways, ranging from reduction of root growth and metabolism, inhibition of root water uptake by blocking water channels, blockage of xylem vessels, and decrease of stomatal aperture (e.g. Poschenrieder and Barceló, 1999; Robb et al., 1980; Schlegel et al., 1987). The soil water potential measurements suggest that the primary metal effect occurred locally in the topsoils, where roots were exposed to metal stress. This does not exclude an active secondary response of the plants at the leaf level down-regulating stomatal water loss in order to avoid excessive water stress, as discussed by Schlegel et al. (1987). The observed shifts of water extraction from the topsoil into the subsoil may in fact indicate that inhibition of water uptake in the topsoil induced compensatory root activity at lower depths. The local reduction of root water extraction activity also does not exclude direct effects of accumulated heavy metals on stomatal regulation. $\mathrm{Zn}$ in particular was highly accumulated in the leaves of the deciduous trees (Günthardt-Goerg and Vollenweider, 2003; Hermle, 2004).

In conclusion, the results support the hypothesis that the uncontaminated subsoil offered a possibility to compensate the reduction in root water extraction in the topsoil under drought, as 
well as metal stress. This was more pronounced in the case of the calcareous subsoil, which is more favourable for root activity than the acidic subsoil. The results also show that heavy metal effects on vegetation of a given composition may vary considerably over time and also between different soils due to differences in growth dynamics of the various plant species, as well as due to shifts in competitiveness of the plants.

\section{Acknowledgements}

The authors are grateful to Werner Attinger, Peter Bleuler, Michael Lautenschläger and Martin Keller for their technical support throughout the experiment. The collaboration of Ueli Bühlmann, Terry Menard, Véronique Michellod, Daniele Pezzotta and Susanne Scheid is highly acknowledged. The project was funded by Swiss National Science Foundation and Swiss Federal Office for Education and Science, COST-Action 837.

\section{References}

Angelov T, Uzunova A and Gaidardjieva K $1993 \mathrm{Cu}^{2+}$ effect upon photosynthesis, chloroplast structure, RNA and protein synthesis of pea plants. Photosynthetica 28, 341-350.

Arduini I, Godbold D L and Onnis A 1994 Cadmium and copper change root-growth and morphology of pinus-pinea and pinus-pinaster seedlings. Physiol Plantarum 92(4), 675-680.

Arduini I, Godbold D L and Onnis A 1995 Influence of copper on root-growth and morphology of pinus-pinea 1 and pinus-pinaster ait seedlings. Tree Physiol. 15(6), 411-415.

Arduini I, Godbold D L, Onnis A and Stefani A 1998 Heavy metals influence mineral nutrition of tree seedlings. Chemosphere 36(4-5), 739-744.

Barceló J and Poschenrieder, Ch 1990 Plant water relations as affected by heavy metal stress: a review. J Plant Nutr. 13(1), 1-37.

Chernenkova T V and Kuperman R G 1999 Changes in the spruce forest communities along a heavy metal deposition gradient on Kola Peninsula. Water Air Soil Pollut. 111(14), 187-200.

Costa G and Spitz E 1997 Influence of cadmium on soluble carbohydrates, free amino acids, protein content of in vitro cultured Lupinus albus. Plant Sci. 128, 131-140.

Darling CTR and Thomas VG 2003. The distribution of outdoor shooting ranges in Ontario and the potential for lead pollution of soil and water. Sci. Total Environ. 313(1-3): 235-243.

Dueck T A 1986 The combined effect of sulphur dioxide and copper on two populations of Trifolium repens and Lolium perenne. In Impact of Heavy Metals and Air Pollutants on Plants. Academisch Proefschrift. pp. 102-114, Free University Press, Amsterdam.
Egli P, Günthardt-Goerg M S, and Körner Ch 1998 Effects of elevated $\mathrm{CO}_{2}$ and soil quality on leaf gas-exchange and above-ground growth in beech-spruce model ecosystems. New Phytol. 140, 185-196.

Ewais E A 1997 Effects of cadmium, nickel and lead to growth, chlorophyll content and proteins of weeds. Biol. Plan. 39(3), 403-410.

Fotovat A and Naidu R 1998 Changes in composition of soil aqueous phase influence chemistry of indigenous heavy metals in alkaline sodic and acidic soils. Geoderma 84(1-3), 213-234.

Günthardt-Goerg M S and Vollenweider P 2003 Cellular injury, heavy metal uptake and growth of poplar, willow and spruce influenced by heavy metals and soil acidity. In COST Action 837, 4th WG2 Workshop, 2002 - Risk assessment and sustainable land management using plants in trace element-contaminated soil. Eds. Michel J. Mench, Bernard Mocquot. pp. 165-171, Institut National de la Recherche Agronomique, Villenave d'Ornon, France.

Helmisaari H S, Makkonen K, Olsson M, Viksna A and Malkonen E 1999 Fine-root growth, mortality and heavy metal concentrations in limed and fertilized Pinus silvestris (L.) stands in the vicinity of a $\mathrm{Cu}-\mathrm{Ni}$ smelter in SW Finland. Plant Soil 209(2), 193-200.

Hermle S 2004 Reactions of a young forest ecosystem to heavy metal stress in the soil. Ph.D. Thesis. ETH Zurich Switzerland, in preparation.

Kahle H 1993. Response of roots of trees to heavy metals. Environ. Exp. Bot. 33(1), 99-119.

Karolewski P and Giertych M J 1994 Influence of toxic metal-ions on phenols in needles and roots, and on root respiration of Scots pine-seedlings. Acta Soc Bot Pol 63(1), 29-35.

Kastori R, Petrovic M and Pertovic N 1992 Effect of excess lead, cadmium, copper and zinc on water relations in sunflower. J Plant Nutr. 15(11), 2427-2439.

Kirkham M 1978 Water relations in cadmium-treated plants. J. Environ. Qual. 7, 334-336.

Klein R M 1985 Effect of acidity and metal ions on water movement through red spruce. In Acid Deposition. Ed. Pape, W P and Adams DD. Plenum Publishing Corporation.

Krebs R, Gupta S K, Furrer G and Schulin R 1998 Solubility and plant uptake of metals with and without liming of sludge-amended soils. J. Environ. Qual. 27(1), 18-23.

Marthaler H P, Vogelsanger W, Richard F and Wierenga P J 1983 A pressure transducer for field tensiometers. Soil Sci. Soc. Am. J 47(4), 624-627.

Oberlander H E and Roth K 1978 Die Wirkung der Schwermetalle Chrom, Nickel, Kupfer, Zink Cadmium, Quecksilber and Blei auf die Aufnahme und Verlagerung von Kalium und Phosphat bei jungen Gerstenpflanzen. Z. Pflanzenernahr. Bodenk. 141, 107-116.

Palazzo A J, Cary T J, Hardy S E, Lee C R 2003 Root growth and metal uptake in four grasses grown on zinccontaminated soils. J Environ. Qual. 32(3), 834-840.

Paul and de Foresta, 1981 Effects du cadmium sur la transpiration du plantes. Bull. Rech. Agron Gembloux 16, 371378.

Poschenrieder Ch and Barceló J 1999 Water relations in heavy metal stressed plants. In Heavy Metal Stress in Plants - From Molecules to Ecosystem. Ed. Prasad MNV and Hagemeyer J. pp. 207-229. 
Prasad M N V 1995 Inhibition of maize leaf chlorophylls, carotenoids and gas-exchange functions by cadmium. Phytosynthetica 31(4), 635-640.

Pukacki P M and Kaminska-Rozek E 2002 Long-term implications of industrial pollution stress on lipids composition in Scots pine (Pinus sylvestris L.) Roots. Acta Physiol. Plant 24(3), 249-255.

Pulford I D and Watson C 2003 Phytoremediation of heavy metal-contaminated land by trees - a review. Environ. Int. 29, 529-540.

Rais D 2004 Monitoring of the soil solution chemistry as influenced by trees in a model ecosystem experiment with heavy metal contaminated soils. Ph.D. Thesis. ETH Zurich, Switzerland, in preparation.

Robb J, Busch L and Rauser W E 1980 Zinc toxicity and xylem vessel wall alterations in white beans. Ann. Bot. 46, 43-50.

Romney E M, Wallace A, Cha J W and Mueller R T 1981 Effect of zone placement in soil on trace metal uptake by plants. J Plant Nutr. 3(1-4), 265-270.
Roth K, Schulin R, Fluhler H and Attinger W 1989 Calibration of time domain reflectometry for water-content measurement using a composite dielectric approach. Water Resour. Res. 26(10), 2267-2273.

Schlegel H, Godbold DL and Huttermann A, et al. 1987 Whole plant aspects of heavy metal induced changes in $\mathrm{CO}_{2}$ uptake and water relations of spruce (Picea abies) seedlings. Physiol. Plant 69(2), 265-270.

Schwartz C, Morel J S, Saumier S, Whiting S N and Baker A J M 1999 Root development of the zinc-hyperaccumulator plant Thlaspi cearulescens as affected by metal origin, content and localisation in soil. Plant Soil 208, 103115 .

Wittig R and Neite H 1989 Distribution of $\mathrm{Pb}$ in the soils of Fagus sylvatica forest in Europe. In Plants and Pollutants in Developed and Developing Countries. pp 199-206. Ed. Ozturk MA. Botany Dept., Science Faculty, Ege University, Izmir, Turkey.

Section editor: M.A. Adams 